\title{
PENGARUH MODEL PEMBELAJARAN BERBASIS MASALAH TERHADAP KEMAMPUAN PEMECAHAN MASALAH MATEMATIKA SISWA KELAS VIII SMP ABDI NEGARA BINJAI
}

\author{
Regina Sabariah Sinaga ${ }^{1}$, Siti Rauni Anjelina Situmorang ${ }^{2}$, \\ reginasabariah@gmail.com \\ sitirauni@gamil.com
}

\begin{abstract}
ABSTRAK
Tujuan penelitian ini untuk menganalisis pengaruh model pembelajaran berbasis masalah terhadap kemampuan pemecahan masalah matematika siswa. Penelitian ini dilakukan di SMP Abdi Negara Binjai. Jenis penelitian ini adalah penelitian Eksperimen Semu dengan desain penelitian Pretest Postest Control Group Design. Instrumen yang digunakan dalam penelitian ini berupa tes kemampuan pemecahan masalah matematika siswa berbentuk uraian sebanyak 5 soal. Berdasarkan hasil uji normalitas diperoleh bahwa kedua populasi berdistribusi normal. Sedangkan hasil uji homogenitas diperoleh bahwa kedua populasi homogen (sama). Temuan hasil penelitian mengungkapkan bahwa model pembelajaran berbasis masalah mempunyai pengaruh yang signifikan terhadap kemampuan pemecahan masalah matematika siswa. Hal ini dapat dilihat dari nilai rata-rata posttest hasil tes kemampuan pemecahan masalah matematika siswa yang telah diajarkan dengan model pembelajaran berbasis masalah adalah sebesar 79,1 dan nilai rata-rata posttest hasil tes kemampuan pemecahan masalah matematika siswa yang telah diajarkan dengan model pembelajaran konvensional adalah sebesar 63,67 sehingga didapatkan bahwa model pembelajaran berbasis masalah memiliki pengaruh sebesar 0,88 dan berada pada level sangat kuat. Kesimpulan hasil penelitian ini adalah bahwa pembelajaran matematika dengan menggunakan model pembelajaran berbasis masalah mempunyai pengaruh yang signifikan terhadap kemampuan pemecahan masalah matematika siswa. Direkomendasikan untuk peneliti selanjutnya penelitian ini hanya fokus pada pokok bahasan bentuk aljabar oleh karena itu untuk dapat di kembangkan pada pokok bahasan lainnya.
\end{abstract}

Kata kunci : Model Pembelajaran Berbasis Masalah; Kemampuan Pemecahan Masalah Matematika 
Jurnal Serunai Ilmu Pendidikan

Vol.6, No.2, Desember 2020

e-ISSN 2621 - 2676, p-ISSN 2528 - 0775

\section{PENDAHULUAN}

Pendidikan memegang peranan yang sangat penting dalam proses peningkatan kualitas sumber daya manusia dan merupakan suatu proses yang terintegrasi dengan proses peningkatan kualitas sumber daya manusia itu sendiri. Menyadari pentingnya proses peningkatan kualitas sumber daya manusia, maka Pemerintah telah berupaya mewujudkan amanat tersebut melalui berbagai usaha pembangunan pendidikan yang lebih berkualitas melalui pengembangan dan perbaikan kurikulum dan sistem evaluasi, perbaikan sarana pendidikan, pengembangan dan pengadaan materi ajar, serta pelatihan bagi guru dan tenaga kependidikan lainnya. Tetapi kenyataan belum cukup dalam meningkatkan kualitas pendidikan.

Kualitas pendidikan pada dasarnya akan berpengaruh kepada meningkatnya ilmu pengetahuan, kemampuan dan kreatifitas yang dimiliki oleh manusia. Salah satu ilmu pengetahuan yang penting untuk dipelajari oleh manusia yaitu matematika. Matematika sebagai ilmu dasar mempunyai peranan yang sangat penting dalam ilmu pengetahuan dan teknologi. Oleh sebab itu, dalam dunia pendidikan matematika dipelajari oleh semua siswa mulai dari tingkat sekolah dasar sampai pada perguruan tinggi dan menjadi salah satu pengukur (indikator) keberhasilan siswa dalam menempuh suatu jenjang pendidikan, serta menjadi materi ujian untuk seleksi penerimaan menjadi tenaga kerja bidang tertentu.

Cockroft mengungkapkan bahwa alasan perlunya belajar matematika adalah sebagai berikut: Matematika perlu diajarkan karena (1) selalu digunakan dalam segala segi kehidupan, (2) semua bidang studi memerlukan keterampilan matematika yang sesuai, (3) merupakan sarana komunikasi yang kuat, singkat, dan jelas, (4) dapat digunakan untuk menyajikan informasi dalam berbagai cara, (5) meningkatkan kemampuan berfikir logis, ketelitian, dan kesadaran keruangan, dan (6) memberikan kepuasan terhadap usaha memecahkan masalah yang menantang.

Mengingat pentingnya peranan matematika dalam jenjang pendidikan di sekolah selaras dengan tujuan pembelajaran matematika itu sendiri. Dalam lampiran Peraturan Menteri No. 22 tahun 2006 tentang standar isi yang menjelaskan bahwa pelajaran matematika di sekolah menengah bertujuan untuk: (1) Memahami konsep matematika, menjelaskan keterkaitan antar konsep dan mengaplikasikan konsep atau algoritma secara luwes, akurat, efisien, dan tepat dalam pemecahan masalah, (2) menggunakan penalaran pada pola dan sifat, melakukan manipulasi matematika dalam membuat generalisasi, menyusun bukti atau menjelaskan gagasan dan pernyataan matematika, (3)memecahkan masalah yang meliputi kemampuan memahami masalah, merancang model matematika, menyelesaikan model dan menafsirkan solusi yang diperoleh, (4) mengomunikasikan gagasan dengan simbol, tabel, diagram atau media lain untuk memperjelas keadaan atau masalah, dan (5) memiliki sikap menghargai kegunaan matematika dalam kehidupan yaitu memiliki rasa ingin tahu, perhatian dan minat dalam mempelajari matematika serta sikap ulet dan percaya diri dalam pemecahan masalah.

Seorang siswa dikatakan berhasil di dalam matematika apabila memiliki lima kemampuan dasar, yaitu; komunikasi ( communications ), koneksi ( conections ), pemecahan masalah ( problem solving ), penalaran ( reasoning ), dan representasi ( representation). Oleh karena itu, guru memiliki peranan yang sangat penting dalam menumbuhkan kemampuan pemecahan masalah matematika dalam diri siswa, baik dalam bentuk metode pembelajaran yang dipakai maupun dalam evaluasi berupa pembuatan soal yang mendukung. 
Kemampuan memahami suatu masalah berhubungan dengan pengalaman yang pernah kita jalani atau masalah-masalah sejenis yang pernah kita hadapi, dan kemampuan menyelesaikannya merupakan dasar untuk bertahan hidup. Dengan demikian, mendidik siswa untuk menjadi pemecah masalah yang baik merupakan hal yang sangat penting di dalam pendidikan.

Salah satu penyebab rendahnya kemampuan pemecahan masalah siswa tersebut, karena siswa jarang diberikan soal-soal yang mengandung indikator kemampuan pemecahan masalah. Sebagai suatu kemampuan yang dimiliki oleh siswa dalam memecahkan suatu masalah, perlu ada beberapa indikator-indikator dari kemampuan pemecahan masalah. Indikatorindikator kemampuan pemecahan masalah menurut Polya adalah:

Pemecahan masalah merupakan kegiatankegiatan yang diklasifikasikan sebagai pemecahan masalah dalam matematika diantaranya menyelesaikan soal cerita dalam

buku teks, menyelesaikan soal-soal tidak rutin atau memecahkan masalah teka-teki, penerapan matematika pada masalah yang dihadapi dalam kehidupan nyata, menciptakan dan menguji konjektur. Pemecahan masalah mengacu fungsi otak anak, mengembangkan daya pikir secara kreatif untuk mengenali masalah dan mencari alternatif pemecahannya. Hal ini sejalan dengan Shadiq mengatakan bahwa: Pemecahan masalah adalah suatu rancangan tindakan ( action) yang dilakukan guru agar siswanya termotivasi untuk menerima tantangan yang ada pada pertanyaan ( soal ) dan mengarahkan siswa dalam proses pemecahannya. Selama proses pemecahan masalah tersebut, para siswa dituntut untuk belajar menggunakan kemampuan berfikir dan bernalarnya sehingga mereka belajar untuk tidak menggunakan kemampuan mengingat saja.

Salah satu pembelajaran matematika yang diduga efektif untuk meningkatakan kemampuan pemecahan masalah siswa adalah menerapkan model pembelajaran berbasis masalah.
Menurut Dutch "pembelajaran berbasis masalah adalah metode instruksional yang menantang siswa agar belajar untuk bekerjasama dalam kelompok untuk mencari solusibagi masalah yang nyata".

Pembelajaran Berbasis Masalah (Problem Based Learning) merupakan suatu model pembelajaran yang melibatkan siswa untuk memecahkan suatu masalah melalui tahap-tahap metode ilmiah sehingga siswa dapat mempelajari pengetahuan yang berhubungan dengan masalah tersebut dan sekaligus memiliki ketrampilan untuk memecahkan masalah. Menurut Boud dan Felleti pembelajaran berbasis masalah adalah suatu pendekatan pembelajaran dengan membuat konfrontasi kepada peserta didik dengan masalah-masalah praktis dalam belajar.

Tahapan model pembelajaran berbasis masalah menurut arends ada lima fase, yaitu; "(1) mengorientasikan siswa pada masalah; (2) mengorganisasi siswa untuk belajar; (3) membimbing penyelidikan individu maupun kelompok; (4) mengembangkan dan menyajikan hasil karya; (5) menganalisis proses pemecahan masalah". Sesuai dengan penelitian yang telah dilakukan sebelumnya oleh Shinta Sari bahwa "Pendekatan pembelajaran berbasis masalah memberikan pengaruh positif terhadap perkembangan kemampuan pemecahan masalah matematika siswa terutama dalam hal mengecek kembali dan menarik kesimpulan".

\section{II.METODE PENELITIAN}

Penelitian ini dilaksanakan di Sekolah Menengah Pertama (SMP) Abdi Negara Binjai yang beralamat di J1. T. Amir Hamzah no. 628 Kel. Jati Karya Kec. Binjai Utara Kota Binjai. Penelitian ini dilaksanakan di semester ganjil. Populasi dalam penelitian ini adalah seluruh siswa kelas VIII SMP Abdi Negara Binjai Adapun sampel dalam penelitian ini adalah kelas VIII-2 sebagai kelas kontrol yang berjumlah 30 siswa yang diajarkan dengan pembelajaran konvensional dan satu kelas dijadikan kelas eksperimen yaitu kelas VIII-3 dengan jumlah siswa 30 orang Jenis penelitian yang digunakan dalam penelitian ini adalah penelitian eksperimen semu (quasi eksperimen). 
Desain yang digunakan dalam penelitian ini adalah desain penelitian eksperimen dengan rancangan penelitian pretest-posttest control group design. Rancangan dalam penelitian ini terdapat dua kelas yang dipilih secara acak, kemudian diberi pretest untuk mengetahui keadaan awal antara kelompok eksperimen yang menggunakan model pembelajaran berbasis masalah dan kelas kontrol menggunakan pembelajaran konvensional.

\section{III.HASIL PENELITIAN}

\section{Deskripsi Hasil Kemampuan Pemecahan Masalah Matematika}

a. Data Hasil Kemampuan Awal (Pretest) Kemampuan Pemecahan Masalah Matematika Siswa kelas eksperimen dan Kelas Kontrol

Sebelum
pembelajaran pada kedua kelas
dengan pembelajaran yang berbeda yakni
dengan model pembelajaran berbasis
masalah dan model pembelajaran konvensional dengan metode ekspositori terlebih dahulu diadakan pretest untuk mengetahui kemampuan awal siswa khusunya kemampuan pemecahan masalah siswa dari kedua kelas tersebut. Data hasil pretest yang diberikan kepada kelas eksperimen dan kelas kontrol dengan jumlah siswa masing-masing sebanyak 30 siswa yang dalam pembelajarannya diperoleh nilai terendah 36 dan nilai tertinggi 84.

Banyak kelas adalah 6 kelas dengan panjang tiap interval kelas adalah 6 . Selanjutnya dapat dilihat bahwa nilai rata-rata kelas berada pada interval 49 - 61. Dan hasil perhitungan pretest pada kelas eksperimen diperoleh nilai varians 124,19, simpangan baku 11,14. Sedangkan pada kelas kontrol diperoleh nilai varians 111,71 dan simpangan bakunya yaitu 10,56. Hasil pemberian pretest diperoleh nilai ratarata dikelas eksperimen 49,5 dan hasil pemberian nilai pretest pada kolas kontrol diperoleh nilai rata-rata 60,2.
Perbedaan nilai rata-rata siswa antara kelas eksperimen dengan kelas kontrol menunjukkan homogen yang berarti kemampuan awal sama. Secara visual penyebaran data kemampuan pemecahan masalah matematika siswa kelas eksperimen yang menggunakan model pembelajaran berbasis masalah dan kelas kontrol yang menggunakan model

pembelajaran konvensional dengan metode ekspositori dapat dilihat pada histogram perbedaan nilai rata-rata, sirnpangan baku, dan varians pretest kelas eksperimen dan kelas kontrol sebagai berikut.

\section{a. Data Hasil Posttest \\ Kemampuan pemecahan} masalah Matematika Siswa Kelas Eksperimen dan Kelas Kontrol

Setelah diberikan pretest pada kedua kelas dan diperoleh $\mathrm{t}$ idak ada perbedaan kemampuan awal siswa, maka dilakukan pembelajaran yang berbeda yakni di kelas eksperimmen dengan model Pembelajaran berbasis masalah dan model pembelajaran konvensional dengan metode ekspositori di kelas kontrol.

Banyak kelas adalah 6 kelas dengan panjang tiap interval kelas adalah 8 . Selanjutnya dapat dilihat bahwa nilai rata-rata kelas berada pada interval 52 - 65. Dari hasil perhitungan posttest pada kelas eksperimen diperoleh nilai rata-rata kemampuan pemecahan masalah matematika siswa adalah 79,1 sedangkan dikelas kontrol di peroleh nilai rata-rata 63,67.

\section{Hasil Uji Analisis}

\section{a. Uji Normalitas}

Uji normalitas ini dilakukan untuk mengetahui apakah sampel yang diteliti berasal dari populasi yang berdistribusi normal atau tidak. Uji normalitas yang digunakan adalah uji Liliefors. Dan sesuai dengan perhitungan maka data berasal dari distribusi normal. 


\section{b. Uji Homogenitas}

Uji homogenitas ini dilakukan untuk mengetahui apakah sampel yang diteliti berasal dari populasi yang berdistribusi homogen atau tidak. Uji homogenitas yang digunakan adalah uji Liliefors. Dan sesuai dengan perhitungan maka data adalah homogeny.

\section{c. Uji Keberartian Koefisien Regresi pada Kelas Eksperimen}

Dimana untuk menguji keberartian koefisien regresi di rumuskan hipotesis sebagai berikut.

T a b e 11 Hasil Perhitungan Keberartian Koefisien Regresi Pada Kelas Eksperimen

\begin{tabular}{llllll}
\hline $\begin{array}{l}\text { Vari } \\
\text { a ns }\end{array}$ & Jk & $\begin{array}{l}\text { D } \\
\text { b }\end{array}$ & RJK & $\begin{array}{l}\text { Fhit } \\
\text { u ng }\end{array}$ & $\begin{array}{l}\text { Fta } \\
\text { b el }\end{array}$ \\
\hline Total & 192320 & 3 & & 8,758 & $\mathbf{4 , 1 9}$ \\
& & 0 & & & \\
Regre & 190084 & 1 & 190084 & 3 & $\mathbf{5 9}$ \\
si (a) &, 8 & &, 8 & & \\
Regre & 532,57 & 1 & 532,57 & & \\
si & 6 & & 6 & & \\
\hline (b/a) & & & &
\end{tabular}

Berdasarkan tabel hasil perhitungan keberartian koefisien regresi di peroleh $\mathrm{F}_{\text {tabel }}$ $=4,1959$. Dengan demikian dapat dilihat bahwa $\mathrm{F}_{\text {hitung }}>\mathrm{F}_{\text {tabel }}$ yaitu $8,7583>4,1959$ maka $\mathrm{H}_{\mathrm{o}}$ di tolak. Jika harga $F_{\text {hitung }}>F_{\text {tabel }}$ maka harga $F_{\text {hitung }}$ yang di peroleh signifikan. Hal ini menunjukkan bahwa koefisien arah regresi untuk kelas eksperimen berarti dengan taraf signifikan 5\%.

\section{d. Uji Linieritas Regresi Pada Kelas Eksperiemen}

Berdasarkan tabe hasil perhitungan ini maka dapat di hitung kelinieritas model regresi pada kelas eksperimen.

Tabel 2 Analisis Varians untuk Uji Kelinieritas Model Regresi Pada Kelas Eksperimen

\begin{tabular}{llllll}
\hline Varian s & Jk & $\begin{array}{l}\text { D } \\
\text { b }\end{array}$ & RJK & $\begin{array}{l}\text { Fhit } \\
\text { u ng }\end{array}$ & $\begin{array}{l}\text { Fta } \\
\text { b el }\end{array}$ \\
\hline Total & 192320 & 3 & & & \\
& & 0 & & & \\
Sisa & 1702,6 & 2 & 60,80 & 0,057 & $\mathbf{2 , 9 4}$ \\
& 24 & 8 & 8 & 8 & $\mathbf{7 6}$ \\
Galat/ & 1517,3 & 1 & 168,5 & & \\
Kel & 33 & 9 & 92 & & \\
\cline { 1 - 2 } Tuna & $\mathbf{1 8 5 , 2 9}$ & $\mathbf{9}$ & $\mathbf{9 , 7 5}$ & & \\
Cocok & $\mathbf{1}$ & & & & \\
\hline
\end{tabular}

Pada tabel 2 tersebut menunjukkan harga $\mathrm{F}_{\text {tabel }}$ di peroleh dengan melihat daftar distribusi $\mathrm{F}$ dengan taraf nyata 5\%. Dengan demikian dapat dilihat bahwa $\mathrm{d}_{\text {pembilang }}=19$ dan $\mathrm{dk}_{\text {penyebut }}=9$ sehingga $\mathrm{F}_{\text {hitung }}<\mathrm{F}_{\text {tabel }}$ yaitu $0,0578<2,9476$ berarti Ho diterima sehingga regresi $\mathrm{Y}$ atas $\mathrm{X}$ linier.

\section{Uji Hipotesis}

Hipotesis yang akan diuji adalah

Ho : $\theta_{12}=\theta_{21}$

$\mathrm{H}$ a $: \theta_{12} \neq \theta_{21}$

Hipotesis yang diujikan

$$
\begin{aligned}
\text { Ho }= & \text { Tidak terdapat pengaruh } \\
& \text { yang signifikan model } \\
& \text { pembelajaran berbasis } \\
& \text { masalah terhadap kemampuan } \\
& \text { pemecahan masalah. } \\
\mathrm{Ha}= & \text { Terdapat pengaruh yang } \\
& \text { signifikan model pembelajaran } \\
& \text { berbasis masalah terhadap } \\
& \text { kemampuan } \\
& \text { masalah. }
\end{aligned}
$$

Oleh karena $i$ tu untuk mengetahui seberapa besar pengaruh model pembelajaran berbasis masalah dapat diperhatikan pada tabel berikut ini:

Tabel 3 Hasil Uji Hipotesis

\begin{tabular}{lllll}
\hline Hubungan & R & $\mathbf{r}^{2}$ & $\begin{array}{l}\mathrm{D}= \\
\mathbf{r}^{2} \times 160\end{array}$ & $\begin{array}{l}\text { Garis } \\
\text { Regre }\end{array}$ \\
& & & $\mathrm{s} \mathrm{i}$ \\
\hline Model & 0,8 & $\mathbf{0 , 7 7 4}$ & $\mathbf{7 7 , 4 4 \%}$ & $\mathrm{Y}=$ \\
Pembelajara & $\mathbf{8}$ & 4 & & $\mathbf{2 8 , 4}$ \\
n berbasis & & & & $\mathbf{1}$ \\
masalah & & & & $+\mathbf{0 , 2 2}$ \\
& & & & $\mathrm{X}$ \\
\hline
\end{tabular}

Dari hasil perhitungan diperoleh $\mathrm{r}$ $=0,88$ karena $r \neq 0$. Maka dapat disimpulkan bahwa pada taraf signifikan 5\% $(0,05)$, terdapat pengaruh model pembelajaran model pembelajaran berbasis masalah terhadap kemampuan pemecahan masalah matematika siswa. Dimana besarnya pengaruh model pembelajaran berbasis masalah terhadap kemampuan pemecahan masalah matematika siswa sebesar $77,44 \%$. Dengan demikian dapat dikatakan bahwa model pembelajaran berbasis masalah berpengaruh sangat besar terhadap kemampuan pemecahan masalah matematika siswa. 


\section{PEMBAHASAN}

Sebelum melakukan penelitian, peneliti memberikan pretest terlebih dahulu dikelas eksperimen dan kelas kontrol. Hal itu di lakukan untuk mengetahui kemampuan awal siswa sebelum diberikannya perlakuan sebagai data nilai awal. Berdasarkan analisis pretest, hasil perhitungan diperoleh nilai rata-rata $(X)$ untuk kelas eksperimen (VIII-2) adalah 49,5 dengan simpangan baku adalah 11,14 . Sementara nilai rata-rata $(X)$ kelas kontrol (VIII-3) adalah 60,2 dengan simpangan baku adalah 10,56. Sehingga dari analisis pretest kelas eksperimen diperoleh $\mathrm{L}_{\mathrm{O}}=0,0352$ sedangkan $\mathrm{L}_{\mathrm{t}}=0,161$. Ini menunjukkan bahwa diperoleh Lo $<\mathrm{L}_{\mathrm{t}}$ pada uji normalitas, sementara itu analisis data awal pretest kelas kontrol diperoleh Lo $=0,0212$ sedangkan $\mathrm{L}_{\mathrm{t}}=0,161$. Ini menunjukkan bahwa diperoleh $\mathrm{L}_{\mathrm{O}}<\mathrm{L}_{\mathrm{t}}$ pada uji normalitas. Uji homogenitas juga menunjukkan hasil yang sama seperti ujinormalitas. Jadi kesimpulannya adalah kedua kelas berasal dari kondisi yang sama dan dapat diberi perlakuan, yaitu kelas eksperimen di beri perlakuan dengan model pembelajaran berbasis masalah dan kelas kontrol dengan model pembelajaran konvensional dengan metode ekspositori.

Proses pembelajaran selanjutnya kelas eksperimen mendapat perlakuan model pembelajaran berbasis masalah dengan langkah-langkah model pembelajaran berbasis masalah yang melalui beberapa tahap seperti: (1) Memberikan orientasi tentang permasalahan kepada peserta didik, (2) mengorganisasikan peserta didik untuk meneliti/belajar, (3) membantu investigasi mandiri dan kelompok, (4) mengembangkan dan mempresentasikan hasil artefak/laporan, (5) menganalisis dan mengevaluasi. Berdasarkan hasil tes yang telah dilakukan di peroleh nilai rata- rata kelas eksperimen (VIII-2) adalah 79,1 dengan simpangan baku adalah 9,1. Sementara nilai rata-rata kelas kontrol (V1ll-3 ) 63,67 Sehingga dari analisis data akhir (posttest) kelas eksperimen diperoleh $\mathrm{L}_{0}=$ 0,0484 sedangkan $\mathrm{Lt}=0,161$. Ini menunjukkan bahwa diperoleh $\mathrm{L}_{\mathrm{O}}<\mathrm{Lt}$ pada uji normalitas, sementara itu analisis data akhir (posttest) kelas kontrol di peroleh Lo $=0,1490$ sedangkan $\mathrm{L}_{\mathrm{t}}=$
Jurnal Serunai Ilmu Pendidikan

Vol.6, No.2, Desember 2020

e-ISSN 2621 - 2676, p-ISSN 2528 - 0775

0,161 . Ini menunjukkan bahwa diperoleh Lo $<\mathrm{L}_{\mathrm{t}}$ pada uji normalitas. Uji homogenitas juga menunjukkan hasil yang sama seperti uji normalitas. Jadi kesimpulannya adalah kedua kelas berasal dari kondisi yang sama.

Berdasarkan uji regresi linear sederhana diperoleh $r_{\text {tabel }}=0,361$ sementara berdasarkan perhitungan yang telah di lakukan di peroleh $\mathrm{r}_{\text {hitung }}=0,88$ berada pada kategori sangat kuat. Dari perhitungan terlihat bahwa $r_{\text {hitung }}>r_{\text {tabel }}(0,88>0,361)$ maka hipotesis yang diajukkan diterima. Model pembelajaran berbasis masalah berpengaruh terhadap kemampuan pemecahan masalah matematika siswa, sebab dalam pembelajaran ini siswa bekerja sama dalam kelompok untuk menemukan masalah pada soal LKS yang diberikan oleh guru sehingga siswa dan guru saling melakukan interaksi berupa tanya jawab apa yang kurang di pahami oleh siswa. Dengan demikian, maka hasilnya dapat dikemukakan bahwa: 1. Terdapat pengaruh yang signifikan model pembelajaran berbasis masalah terhadap kemampuan pemecahan masalah matematika siswa kelas VIII SMP Abdi Negara Binjai Tahun Pelajaran 2017/2018. 2. Kemampuan pemecahan masalah siswa yang diajarkan dengan menggunakan model pembelajaran berbasis masalah ternyata lebih baik dari pada pembelajaran langsung.

\section{KESIMPULAN DAN SARAN \\ Kesimpulan}

1. Terdapat pengaruh yang signifikan model pembelajaran berbasis masalah terhadap kemampuan pemecahan masalah matematika siswa kelas VIII SMP Abdi Negara Binjai, dengan nilai $r_{x y}=0,88$ (berada pada level sangat kuat).

2. Kemampuan pemecahan masalah siswa yang diajarkan dengan menggunakan model pembelajaran berbasis masalah ternyata lebih baik dari pada pembelajaran langsung, dimana nilai rata-rata pada kelas eksperimen lebih tinggi dari pada kelas kontrol, yaitu $x_{\text {eksperimen }}=79,1$ dan

$x_{\text {kontrol }}=63,67$.

\section{Saran}

1. Untuk guru model pembelajaran berbasis masalah dapat menjadi salah satu model pembelajaran yang dapat di terapkan dalam proses mengajar.

2. Untuk peneliti selanjutnya penelitian ini 
hanya fokus pada pokok bahasan bentuk Aljabar oleh karena itu untuk dapat di kembangkan pada pokok bahasan lainnya.

\section{DAFTAR PUSTAKA}

Abdul Rofik, Pembelajaran Matematika Model Contextual Teaching and Learning dengan Pendekatan Problem Possing Berbantuan E-Learning Materi Dimensi Tiga Kelas X Untuk Meningkatkan Kemampuan Pemecahan Masalah, dalam Jurnal Euclid, Vol 2, No 2, 2011.

Abdurrahman, Mulyono. Pendidikan Bagi Anak Berkesulitan Belajar, Jakarta: Rineka Cipta,2010.

Arikunto, Suharsimi. Prosedur Penelitian Suatu Pendekatan Praktik, Jakarta: Rieneka Cipta, 2007

Arikunto, Suharsimi. Dasar-Dasar Evaluasi Pendidikan Edisi 2, Jakarta: Bumi Aksara, 2016

Diyah Hoiriyah,"Peningkatan Kemampuan Pemecahan Masalah Matematik Dan Self-Efficacy Siswa Melalui Pembelajaran Berbasis Masalah Di MAN 1 Padangsidimpuan", Vol 3, No $1,2015$.

Gd. Gunantara,"Penerapan Model Pembelajaran Problem Based Learning Untuk Meningkatkan Kemampuan Pemecahan Masalah Matematika Siswa Kelas V”, Jurnal Mimbar PGSD Universitas Pendidikan Ganesha, Vol 2, No 1, 2014.

Harlinda Fatmawati, dkk, Analisis berfikir kritis siswa dalam pemecahan masalah matematika berdasarkan polya pada pokok bahasan persamaan kuadrat(penelitian pada siswa kelas $x$ smk muhammadiyah 1 sragen tahun pelajaran 2013/2014), dalam jurnal Elektronik Pembelajaran Matematika, Vol 2, No 9, 2014.
Jurnal Serunai Ilmu Pendidikan

Vol.6, No.2, Desember 2020

e-ISSN 2621 - 2676, p-ISSN 2528 - 0775

Jihad, Asep, dkk. Evaluasi Pembelajaran, Yogyakarta: Multi Pressindo, 2012.

Mudjiono dan Dimyanti, Belajar dan Pembelajaran, Jakarta: PT Rineka Cipta, 2013.

Ngalimun, Strategi Dan Model Pembelajaran, Banjarmasin: Aswaja Pressindo, 2012.

Nurma Angkotasan,"Keefektifan Model Problem Based Learning Ditinjau Dari Kemampuan Pemecahan Masalah Matematis", Jurnal Matematika Dan Pendidikan Matematika, Vol 3, No 1, 2014.

Rahmi Ramadhani,"Peningkatan Kemampuan Pemecahan Masalah Matematika Siswa SMA Melalui Model Pembelajaran Based Learning Berbantuan Software Geogebra", Jurnal Ilmiah Integritas, Vol 2, No 1, 2016.

Rusman, Model-Model Pembelajaran, PT. Raja Grafindo Persada,2010.

Shadiq, Fadjar. Model-Model Pembelajaran Matematika SMP, Yogyakarta: Pusat Pengembangan dan Pemberdayaan Pendidik dan Tenaga Kependidikan (PPPPTK) Matematika, 2009.

Shinta Sari, "Pengaruh Pendekatan Pembelajaran Berbasis Masalah Terhadap Kemampuan Pemecahan Masalah Matematika Siswa Kelas VIII SMP Negeri 1 Padang” , Jurnal Pendidikan Matematika, Vol 3, No 2, 2014.

Shoimin, Aris. 68 Model Pembelajaran Inovatif Dalam Kurikulum 2013, Yogyakarta: Ar-Ruzz Media, 2014. 
Jurnal Serunai Ilmu Pendidikan

Vol.6, No.2, Desember 2020

e-ISSN 2621 - 2676, p-ISSN 2528 - 0775

Sri Rukiyatiningsih, "Peran Komite Sekolah Dalam Meningkatkan Mutu Sekolah Di SMP $N \quad 1$ Sokobanah Kabupaten Sampang” Jurnal Pendidikan, Vol 5, No 1, 2013.

Sudirman, Interaksi dan Motivasi Belajar Mengajar, Jakarta: Rajawali Pers, 2011.

Sudjana, Metode Statistika, Bandung : Tarsito, 2012.
Sugiyono, Metode Penelitian Pendidikan, Bandung: Alfabeta, 2015.

Trianto, Mendesain Model Pembelajaran Inovatif-Progresif, Jakarta; Kencana , 2009.

Wena, Made. Strategi Pembelajaran Inovatif Kontemporer, Jakarta: PT Bumi Aksara, 2011. 